\title{
Analisis Keberlanjutan Pengelolaan Perkebunan Kelapa Sawit Pola Inti-Plasma Di PT. Bio Nusantara TeknologiKabupaten Bengkulu Tengah
}

\author{
Iskandar $^{1}$, Satria Putra Utama ${ }^{2}$, Muhammad Faiz Barchia ${ }^{3}$ \\ ${ }^{1}$ Program Studi Sumber Daya Alam dan Lingkungan Fakultas Pertanian Universitas Bengkulu \\ ${ }^{2}$ Jurusan Agribisnis Fakultas Pertanian Universitas Bengkulu. \\ ${ }^{3}$ Jurusan Ilmu Tanah Fakultas Pertanian Universitas Bengkulu. \\ email: ihbio@yahoo.co.id
}

\begin{abstract}
ABSTRAK
Tuntutan global saat ini yang senantiasa meneriakkan kelestarian atau produksi yang berkelanjutan sudah tidak dapat dihindari lagi, termasuk juga didalam pengelolaan perkebunan kelapa sawit khususnya kemitraan pola inti-plasma, yang harus segera dicari solusi atau pendekatannya. Penelitian ini bertujuan untuk menilai indeks dan status keberlanjutan pengelolaan perkebunan kelapa sawit pola inti-plasma di PT. Bio Nusantara Teknologi yang berkelanjutan dari dimensi ekologi, ekonomi, sosial- budaya, teknologi-infrastruktur, dan hukum-kelembagaan, serta mengidentifikasi atribut yang sensitif terhadap keberlanjutan pengelolaan perkebunan kelapa sawit pola inti inti-plasma di PT. Bio Nusantara Teknologi. Analisis keberlanjutan dilakukan dengan metode pendekatan Multi Dimensional Scaling (MDS) dengan teknik kelapa sawit Rap-Insus (Rapid Appraisal Index Sustainability of palm oil management). Hasil penelitian menunjukkan bahwa status keberlanjutan pengelolaan perkebunan kelapa sawit pola inti-plasma di PT. Bio Nusantara Teknologi Kabupaten Bengkulu Tengah yang berdasarkan atas 5 dimensi dinyatakan cukup berkelanjutan dengan indeks keberlanjutan multidimensi sebesar 53,18, dimana dimensi yang cukup berkelanjutan ada 3 dimensi yaitu ekologi, ekonomi, dan sosial-budaya, sedangkan 2 dimensi lainnya yaitu teknologi-infrastruktur dan hukum-kelembagaan berada pada status kurang berkelanjutan.
\end{abstract}

Kata Kunci: Perkebunan Kelapa Sawit, Pengelolaan Inti-Plasma, Multidimensi,Analisis Keberlanjutan,

\section{PENDAHULUAN}

Kelapa sawit di Indonesia saat ini merupakan komoditas primadona, perkembangan luas lahannya dari waktu ke waktu terus berkembang pesat dan bukan lagi merupakan monopoli dari perkebunan besar Negara (PBN) atau perkebunan besar swasta (PBS), melainkan perkebunan rakyat (PR) juga sudah berkembang dengan cepat. Hal ini terlihat dari laju perkembangan luas lahan dan produksi dari perkebunan kelapa sawit di Indonesia, dimana pada tahun 2004 seluas 5.28 juta ha, telah meningkat menjadi 10,96 juta ha pada tahun 2014 (meningkat rata-rata 10,35\% per tahun). Produksi minyak sawit juga meningkat dari 10,83 juta ton (1997) menjadi 29,34 juta ton pada tahun 2014, atau meningkat rata-rata 17,09\% per tahun (Ditjenbun 2015). Beberapa isu nasional seperti pengangguran, kemiskinan, kelangkaan energi dan adanya kerusakan lingkungan di Indonesia, menjadikan kebijakan pembangunan pertanian mulai fokus kepada komoditas perkebunan, dengan harapan dapat berperan besar di dalam peningkatan di bidang ekonomi, sosial, dan lingkungan, dan tanaman kelapa sawit termasuk dalam komoditas prioritas utama untuk diunggulkan.

Pemerintah telah menerbitkan UU Perkebunan No. 39/tahun 2014 yang mencantumkan ketentuan mengenai pembangunan perkebunan berkelanjutan, yangintinya mewajibkan perusahaan untuk mengikuti standar pembangunan kebun kelapa sawit yang berkelanjutan dengan cara mengikuti semua ketentuan peraturan dan perundangundangan yang berlaku di Indonesia, agar seluruh perusahaan perkebunan peduli dan 
memperhatikan faktor ekonomi, sosial masyarakat, dan lingkungan sekitarnya, dengan wujud nyatanya adalah meningkatkan kesejahteraan masyarakat melalui pemberdayaan perekonomian masyarakat khususnya pembangunan kebun kelapa sawit yang lahannya dimiliki sendiri oleh masyarakat tersebut.

Program pengembangan dan pembangunan perkebunan kelapa sawit dengan pola intiplasma (kemitraan) dalam skala besar sangat menguntungkan bagi berbagai aspek, terutama ekonomi, dan sosial masyarakat. Ditinjau dari aspek ekonomi, perkebunan kelapa sawit dapat mendukung industri dalam negeri berbasis produk berbahan dasar kelapa sawit, selain itu dengan terbangunnya banyak sentra ekonomi di wilayah baru akan mendukung pembangunan ekonomi regional. Ditinjau aspek sosial terjadi penyerapan tenaga kerja dalam jumlah besar dan memperkecil kesenjangan pendapatan petani dengan pengusaha perkebunan. Masalah lain yang sering muncul adalah adanya tekanan pihak masyarakat sekitar kebun yang semakin meningkat akibat pola kemitraan yang masih menimbulkan kecemburuan sosial. Karena itu perlu sistem dan pola kemitraan inti dengan plasma yang mengedepankan pembinaan dan pemberdayaan masyarakat di sekitar perkebunan, serta membangun kelembagaan petani (kelompok tani dan koperasi) yang dinamis dan produktif, sehingga hubungan antara masyarakat dengan perusahaan perkebunan dapat saling memahami dan saling menguntungkan.

Dalam penjelasan Undang-Undang No.9/Tahun 1997 tentang Kemitraan memuat mengenai definisi kemitraan pola inti plasma, yaitu: Pola inti plasma adalah hubungan kemitraan antara usaha kecil dengan usaha menengah atau usaha besar, yang di dalamnya usaha menengah atau usaha besar bertindak sebagai inti dan usaha kecil sebagai plasma, perusahaan inti melaksanakan pembinaan mulai dari penyediaan sarana produksi, bimbingan teknis, sampai dengan pemasaran hasil produksi.Meskipun diyakini memberikan kontribusi besar dalam pembangunan daerah dan perekonomian nasional, pembangunan agribisnis kelapa sawit harus dilaksanakan dengan tetap memperhatikan aspek keberlanjutan, sehingga menjamin kelestarian lingkungan dan tanggung jawab sosial masyarakat sekitar. Ciri utama penggunaan lahan berkelanjutan adalah berorientasi jangka panjang, dapat memenuhi kebutuhan saat ini tanpa mengorbankan potensi untuk masa datang, pendapatan perkapita meningkat, kualitas lingkungan dapat di pertahankan atau bahkan ditingkatkan, mempertahankan produktifitas dan kemampuan lahan serta mempertahankan lingkungan dari ancaman degradasi (Sabiham, 2005).

\section{METODE PENELITIAN}

\section{Waktu Dan Tempat Penelitian}

Penelitian ini dilaksanakan pada bulan September sampai dengan Desember 2017 di Perkebunan Inti-Plasma PT. Bio Nusantara Teknologi, yang kantornya terletak di Desa Tanjung Sakti (24 Km sebelah Utara dari Kota Bengkulu), Kecamatan Pondok Kelapa, Kabupaten Bengkulu Tengah, Provinsi Bengkulu.

\section{Jenis Dan Metode Pengumpulan Data}

Data yang digunakan dalam penelitian ini terdiri dari data primer dan data sekunder.Data primer diperoleh melalui observasi langsung ke lapangan, wawancara dengan masyarakat dan tokoh masyarakat, pengusaha perkebunan, kelompok tani, dan aparat pemerintah.Diskusi mendalam dilakukan juga dengan para pakar yang mencakup akademisi,aparat pemerintah dan tokoh masyarakat.Untuk mendapatkan datadari para responden dengan cara menggunakan kuesioner. Responden dipilih dengan teknik purposive sampling (sample bertujuan) yang terdiri dari pemangku kepentingan utama yaitu: petani plasma, kelompok tani, dan dari pihak perusahaan perkebunan PT. Bio Nusantara Teknologi selaku kebun inti.Data sekunder diperoleh melalui dokumen-dokumen dari: PT. Bio Nusantara Teknologi, BPS, dan Badan Pusat Statistik (BPS).

\section{Analisis Data}

Analisis Indeks dan Status Keberlanjutan Pengelolaan Perkebunan Kelapa Sawit Pola 
Inti-Plasma dilakukan dengan metode pendekatan Multi Dimensional Scaling (MDS) dengan teknik Rap-Insus palm oil (Rapid Appraisal-Index Sustainability of palm oil Management) yang telah dimodifikasi dari program RAPFISH (Kavanagh, 2001; Pitcher and Preikshot, 2001; Fauzi dan Anna, 2002). Analisis keberlanjutan ini, dinyatakan dalam Indeks Keberlanjutan Pengelolaan Perkebunan Kelapa Sawit Pola Inti-Plasma. MDS disebut sebagai suatu prosedur yang memungkingkan peneliti dapat menentukan citra persepsi relatif suatu objek (perceptual mapping).

Tahapan kegiatan dan analisis yang dilaksanakan dalam penelitian ini tertera pada Gambar 1.

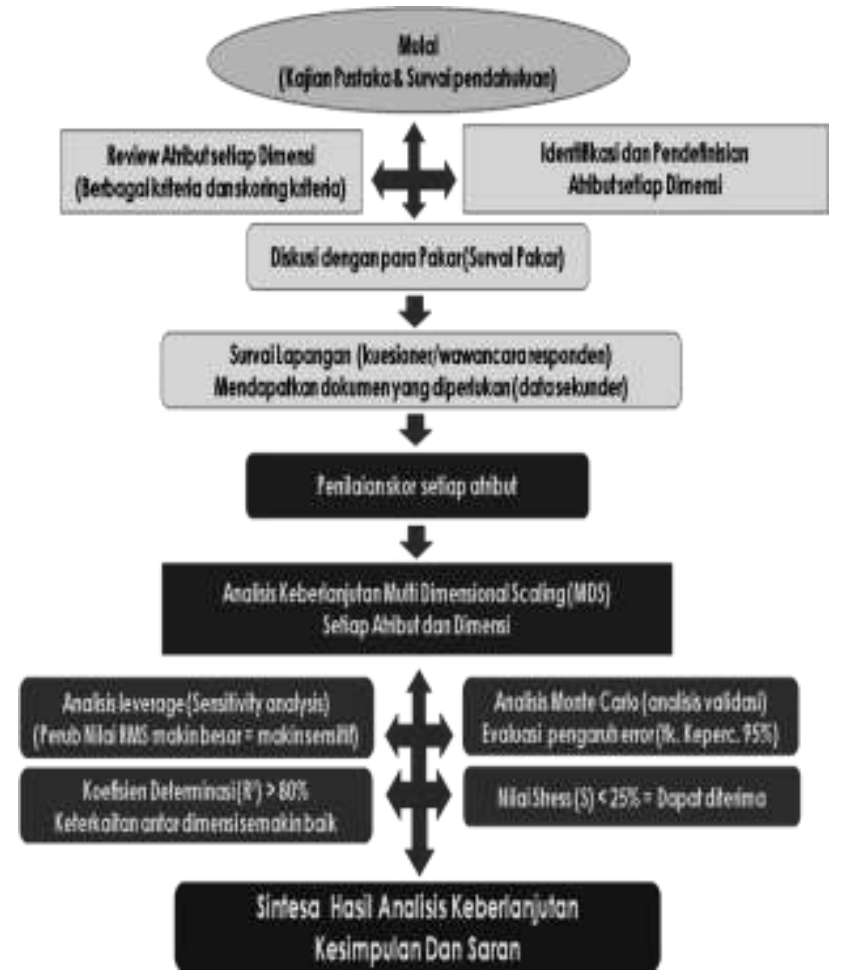

Gambar1. Tahapan Kegiatan \&Analisis Penelitian

Nilai indeks keberlanjutan setiap dimensi dikelompokkan dalam empat tingkatan dapat dilihat pada Tabel 1.berikut ini,

Tabel1. Kategori status keberlanjutan pengelolaan berdasarkan nilai indeks

\begin{aligned} & \hline \multicolumn{1}{c}{ Nilai Indeks } \multicolumn{1}{c}{ Kategori } \\ & \hline $0,00-25,00$ Buruk (tidak berkelanjutan) \\ & $25,01-50,00$ Kurang (kurang berkelanjutan) \\ & $50,01-75,00$ Cukup (cukup berkelanjutan) \\ & $75,01-100,00$ Baik (sangat berkelanjutan) \\ & \hline\end{aligned}

Sumber: Ruslan, dkk. 2013
Melalui metode MDS, maka posisi titik keberlanjutan dapat divisualisasikan melalui sumbu horizontal dan sumbu vertikal. Dengan proses rotasi, maka posisi titik dapat divisualisasikan pada sumbu horizontal dengan nilai indeks keberlanjutan diberi nilai skor 0 (buruk) dan 100 (baik). Jika sistem yang dikaji mempunyai nilai indeks keberlanjutan lebih besar dari 50, maka sistem dikatakan baik (cukup atau sangat berkelanjutan).Tetapi jika nilai indeks kurang dari 50 dikatakan buruk (kurang atau tidak berkelanjutan

Analisis leverage digunakan untuk mengetahui atribut-atribut yang secara sensitif mempengaruhi tingkat keberlanjutan pengelolaan perkebunan kelapa sawit pola intiplasma. Perubahan nilai Root Mean Square (RMS) merupakan nilai yang diperoleh dari hasil akhir analisis leverage, semakin besar perubahan nilai RMS maka semakin sensitif peranan atribut tersebut dalam meningkatkan status keberlanjutan pengelolaan perkebunan kelapa sawit pola inti-plasma. Suwarno (2011) mengemukakan atribut yang dipilih sebagai faktor pengungkit utama merupakan atribut yang memiliki nilai RMS tertinggi sampai dengan nilai setengahnya dari tiap tiap dimensi keberlanjutan.

Analisis Monte Carlo merupakan rangkaian dalam metode Rap-Insus palm oil yang dilakukan untuk menduga tingkat kesalahan acak (random error) pada model yang dihasilkan dari analisis MDS untuk semua dimensi pada tingkat kepercayaan 95\%. Semakin kecil selisih nilai MDS dan analisis Monte Carlo maka semakin baik model yang dihasilkan metode Rap-Insus palm oil. Nilai Stress (S) yang dapat diterima pada analisis Monte Carlo jika nilainya kurang dari 25\%. Semakin besar nilai $\mathrm{R}^{2}$ (squared correlation) atau mendekati $100 \%$ mengindikasikan bahwa keterkaitan antara dimensi sangat kuat.

\section{HASIL DAN PEMBAHASAN}

Perkebunan kelapa sawit PT. Bio Nusantara Teknologi memiliki luas lahan inti sebesar 6.434,58 Ha (data PT. Bio Nusantara Teknologi tahun 2012), dimana tata guna lahan terdiri dari TM 4.091,41 Ha, TBM $210 \mathrm{Ha}$, emplasmen 
(termasuk jalan) 400,00 $\mathrm{Ha}$, areal cadangan 447,00 Ha, serta areal konservasi 1.286,17 Ha.

Pada saat ini, data luas kebun Plasma PT. Bio Nusantara Teknologi secara keseluruhan tercatat $=786,04 \mathrm{Ha}$, terdiri dari kebun Plasma yang kemitraannya masih bersifat hanya bantuan bibit (sebelum tahun 2011) $=411,01 \mathrm{Ha}$, dan kebun plasma pola kemitraan inti-plasma (dimulai tahun 2011) $=375,03$ Ha,seperti terlihat pada Gambar 2.

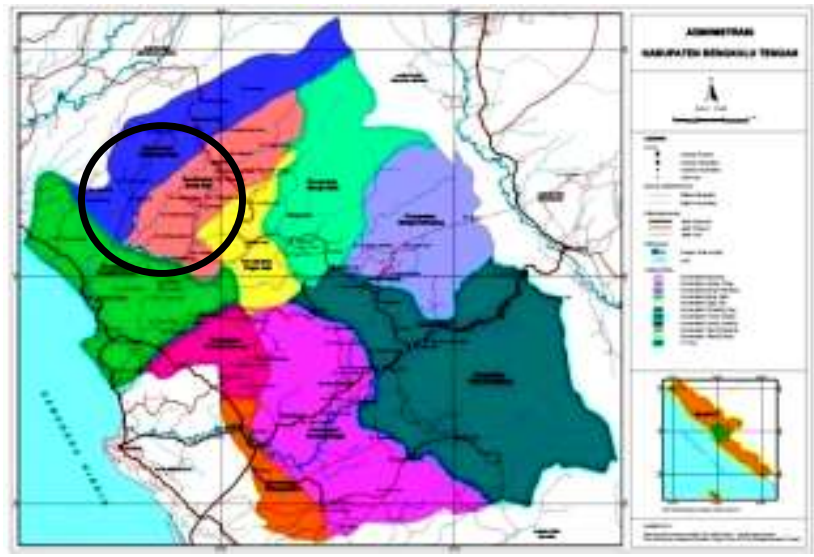

Gambar2.Peta lokasi penelitian kebun inti-plasma PT. Bio Nusantara Teknologi

\section{Analisis Keberlanjutan Multidimensi}

Hasil analisis keberlanjutan dengan RAPInsus menunjukkan bahwa Keberlanjutan Pengelolaan Perkebunan Kelapa Sawit Pola Inti-Plasma di PT. Bio Nusantara Teknologi Kabupaten Bengkulu Tengah yang berdasarkan atas lima dimensi yaitu dimensi ekologi (10 atribut), ekonomi (14 atribut), sosial-budaya (12 atribut), teknologi-infrastruktur (12 atribut), dan hukum-kelembagaan (10 atribut) yang secara keseluruhan terdiri dari 58 atribut, berada pada nilai indeks sebesar 53,18 dengan status Cukup Ber-kelanjutan, seperti yang tersaji pada Gambar 3.

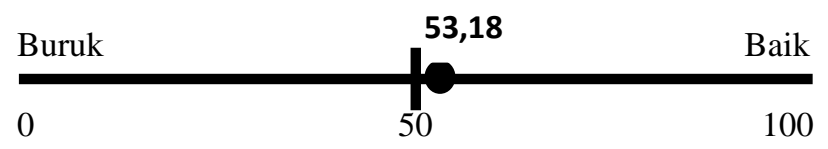

Gambar 3. Indeks Keberlanjutan Pengelolaan

Hasil analisis RAP-Insus juga menunjukkan hubungan keterkaitan antar dimensi yang diukur dengan Squared Correlation $\left(\mathrm{R}^{2}\right)$ sebesar 0,8929 $(89,29 \%)$. Hal ini mengindikasikan bahwa keterkaitan antara dimensi kuat (mendekati
100\%). Sedangkan untuk mengevaluasi error dalam proses ordinasi diperoleh nilai Stress sebesar $20,79 \% \quad(<25 \%)$ mengindikasikan tingkat kesalahannya dapat diterima seperti pada Tabel 2.

Tabel 2. Hasil analisis penentuan indeks keberlanjutan

\begin{tabular}{lcccc}
\hline \multicolumn{1}{c}{ Dimensi } & MDS & $\begin{array}{c}\text { Monte } \\
\text { Carlo }\end{array}$ & $\begin{array}{c}\text { Stress } \\
(\%)\end{array}$ & $\begin{array}{c}\mathrm{R}^{2} \\
(\%)\end{array}$ \\
\hline Ekologi & 56,01 & 55,85 & 22,76 & 90,59 \\
Ekonomi & 58,41 & 58,24 & 20,79 & 88,44 \\
Sosial Budaya & 60,10 & 59,63 & 20,34 & 91,28 \\
Teknologi Infrastruktur & 49,17 & 49,33 & 18,28 & 87,08 \\
Hukum Kelembagaan & 42,19 & 42,60 & 21,75 & 89,03 \\
\hline Multidimensi & 53,18 & 53,13 & 20,79 & 89,29 \\
\hline
\end{tabular}

Sumber: Hasil pengolahan data primer 2017

Berdasarkan informasi tentang status keberlanjutan dari masing-masing dimensi maka diharapkan upaya perbaikan dapat dilakukan secara tepat pada dimensi dan atribut yang masih lemah. Indeks keberlanjutan dari dimensi ekologi, ekonomi, dan sosial budaya termasuk pada kategori status cukup berkelanjutan sedangkan dimensi Teknologi-Infrastruktur serta Hukum-Kelembagaan termasuk pada kategori status kurang berkelanjutan, seperti ditunjukkan pada Gambar 4.

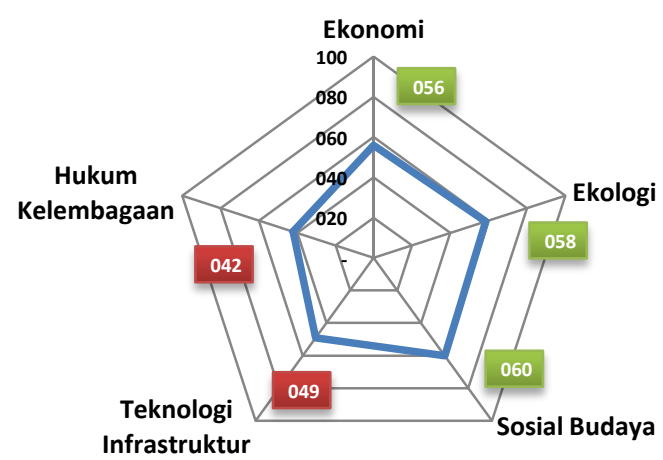

Gambar 4. Diagram layang-layang Indeks Keberlanjutan Dimensi

\section{AnalisisDimensi Ekologi}

Berdasarkan hasil analisis ordinasi dimensi ekologi pada pengelolaan perkebunan kelapa sawit pola inti-plasma di PT. Bio Nusantara Teknologi kabupaten Bengkulu Tengah berada pada nilai indeks 56,01 dengan status cukup berkelanjutan. Hal ini berarti bahwa pengelolaan ini sudah cukup baik dari aspek ekologi, walaupun masih memerlukan perbaikan dan perhatian terutama padaatribut-atribut dalam 
kondisi yang masih kurang atau buruk, seperti terlihat pada Gambar 5.

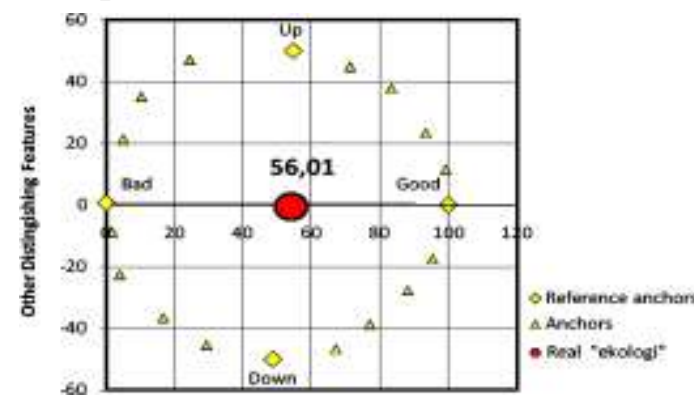

Gambar 5. Analisis keberlanjutan dimensi ekologi

Hasil analisis leverage menunjukkan terdapat empat atribut yang paling sensitif pada dimensi ekologi, yaitu: (1) jumlah bulan kering, (2) tingkat serangan hama dan penyakit, (3) tindakan konservasi pada lahan miring dan (4) kelas kesesuaian lahan, seperti yang tertera pada Gambar 6.

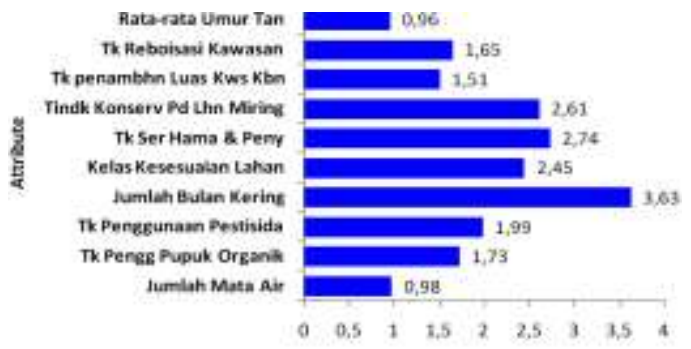

Gambar 6. Sensitivitas atribut dimensi ekologi

Dari analisis leverage ini dapat dimaknai bahwa untuk meningkatkan indeks keberlanjutan dimensi ekologi, kesesuaian faktor iklim curah hujan yang merata sepanjang tahun tanpa bulan kering yang berkepanjangan serta kesesuaian lahan yang sangat dibutuhkan untuk pertumbuhan dan peningkatan produksi, begitu pula dengan serangan hama penyakit terutama serangan hama babi pada saat pembibitan dan tanaman belum menghasilkan harus dapat diatasi dengan baik, serta tindakan-tindakan konservasi pada lahan miring seperti pembuatan teras dan tapak kuda pada tanaman sangat menunjang bagi peningkatan indeks keberlanjutan.

\section{AnalisisDimensi Ekonomi}

Berdasarkan hasil analisis ordinasi dimensi ekonomi pada pengelolaan perkebunan kelapa sawit pola inti plasma di PT. Bio Nusantara Teknologi kabupaten Bengkulu Tengah berada pada nilai indeks 58,41 dengan status cukup berkelanjutan. Hal ini berarti bahwa pengelolaan saat ini sudah cukup baik dari aspek ekonomi, walaupun masih memerlukan perbaikan dan perhatian terutama pada atribut-atribut dalam kondisi yang masih kurang atau buruk, seperti terlihat pada Gambar 7.

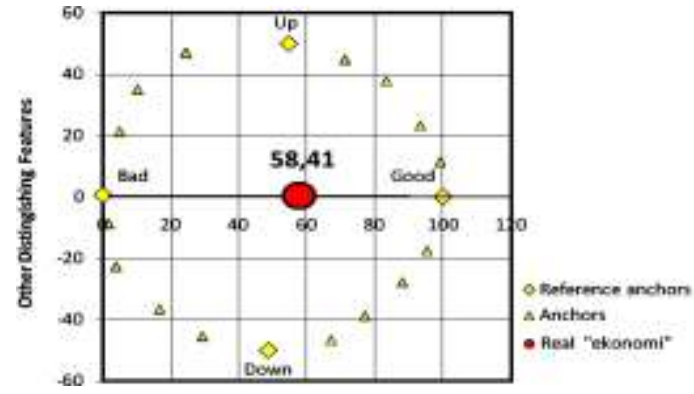

Gambar 7. Analisis keberlanjutan dimensi ekonomi

Hasil analsisi leverage menunjukkan terdapat empat atribut yang paling sensitif pada dimensi ekonomi, yaitu: (1) tingkat pemberdayaan petani dalam kegiatan perkebunan kelapa sawit, (2) keuntungan usaha tani kelapa sawit, (3) kontribusi penjualan side product (cangkang, jangkos, dll) terhadap penetapan harga tbs petani, (4) tingkat kemudahan mendapatkan pinjaman pendanaan, seperti tertera pada Gambar 8.

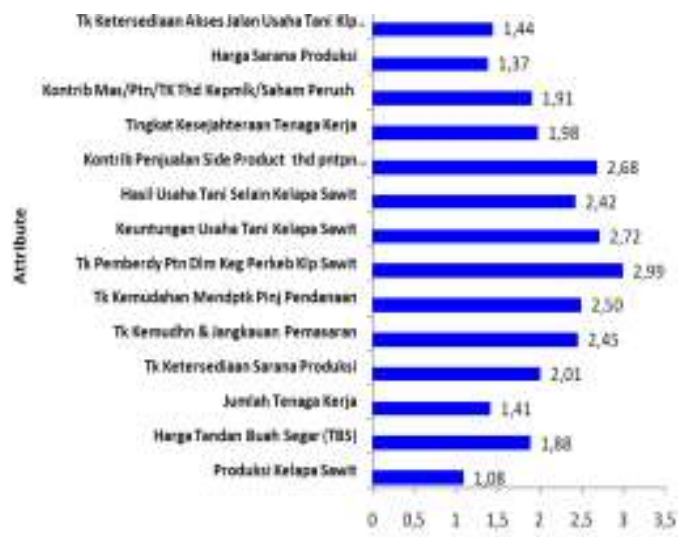

Gambar 8. Sensitivitas atribut dimensi ekonomi

Pemberdayaan petani yang efektif akan membuat petani menjadi lebih adaptif terhadap segala bentuk perubahan yang terjadi di lingkungannya, begitu pula dengan keuntungan usaha tani merupakan hal penting yang harus dicapai agar keberlanjutan usaha tani dan kesejahteraan keluarga dapat ditingkatkan.

Kontribusi penjualan side product terhadap penetapan harga tbs petani haruslah dijamin 
untuk dimasukkan, sehingga dapat meningkatkan pendapatan usaha tani. Begitu pula dengan tingkat kemudahan mendapatkan pinjaman pendanaanharuslah tersedia, agar peningkatan usaha tani dapat terwujud.

\section{AnalisisDimensi Sosial Budaya}

Berdasarkan hasil analisis ordinasidimensi sosial-budaya pada pengelolaan perkebunan kelapa sawit pola inti-plasma di PT. Bio Nusantara Teknologi kabupaten Bengkulu Tengah berada pada nilai indeks60,10 dengan status cukup berkelanjutan. Hal ini berarti bahwa pengelolaan saat ini sudah cukup baik dari aspek sosial budaya, walaupun masih memerlukan perbaikan dan perhatian pada atribut yang masih kurang, seperti terlihat pada Gambar 9.

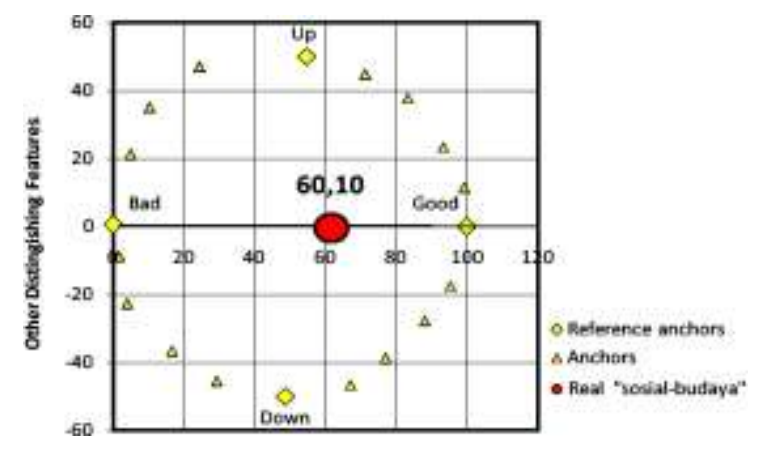

Gambar 9. Analisis keberlanjutan dimensi sosial budaya

Hasil analisis leverage menunjukkan terdapat empat atribut yang paling sensitif pada dimensi sosial budaya, yaitu: (1) rata-rata umur petani, (2) rata-rata pendidikan formal petani, (3) pandangan masyarakat terhadap usaha tani, dan (4) alokasi waktu untuk usaha tani, seperti yang tertera pada Gambar 10.

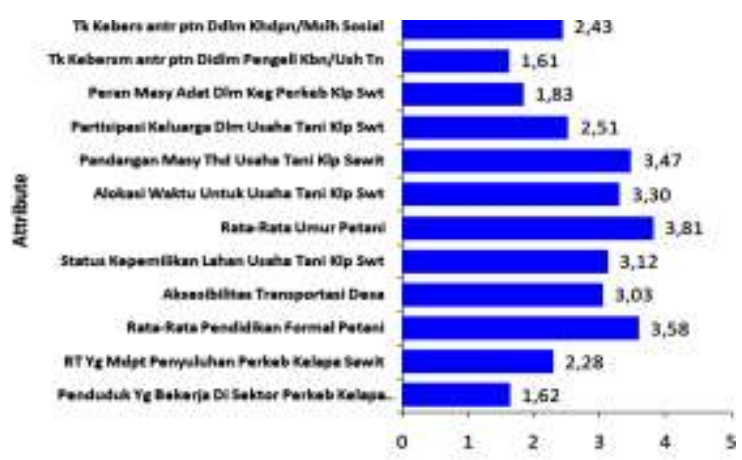

Gambar 10. Sensitivitas atribut dimensi sosial budaya
Tingkat umur/usia petani sangat menentukan, khususnya usia produktif dimana petani dapat berkontribusi maksimal terhadap semua tahapan kegiatan usaha taninya. Pendidikan formal petani juga sangat menentukan kemampuan para petani untuk dapat memanfaatkan teknologi yang tepat guna, dan memiliki wawasan yang luas terhadap upaya peningkatan usaha taninya.

Pandangan masyarakat terhadap usaha tani kelapa sawit juga sangat menentukan, tingginya tingkat penerimaan masyarakat yang dibarengi dengan tingginya keterlibatan masyarakat didalam segala bentuk kegiatan didalam usaha tanidapat meningkatkan lapangan kerja dalam usaha tani kelapa sawit, akhirnya diharapkan alokasi waktu masyarakat khususnya petani akan semakin tinggi pada usaha taninya.

\section{AnalisisDimensi Teknologi-Infrastruktur}

Berdasarkan hasil analisis ordinasi dimensi teknologi-infrastruktur pada pengelolaan perkebunan kelapa sawit pola inti-plasma di PT. Bio Nusantara Teknologi kabupaten Bengkulu Tengah berada pada nilai indeks 49,17 dengan status kurang berkelanjutan.Hal ini berarti bahwa pengelolaan saat ini pada aspek teknologi-infrastruktur masih kurang dan memerlukan perhatian/perbaikan, seperti terlihat pada Gambar 11.

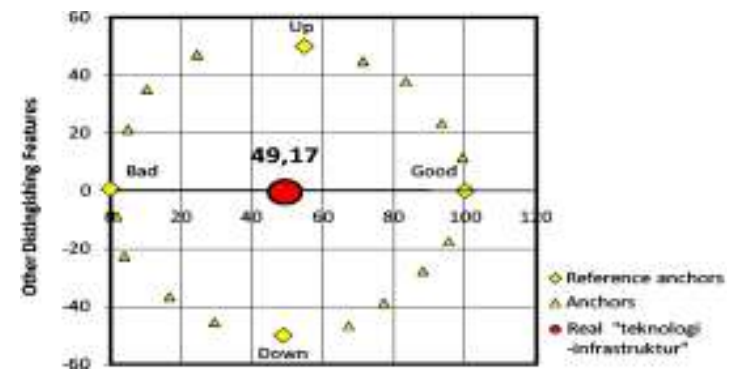

Gambar 11. Analisis keberlanjutan dimensi teknologiinfrastruktur

Hasil analisis leverage menunjukkan terdapat empat atribut yang paling sensitif pada dimensi teknologi infrastruktur agar dapat meningkat menjadi berkelanjutan, yaitu: (1) tingkat kemauan petani untuk menanam dengan bibit unggul yang lebih berkualitas, (2) standarisasi mutu panen kelapa sawit, (3) ketersediaan industri pengolahan hasil kelapa sawit, dan (4) tingkat penguasaan dan penerapan teknologi, seperti yang tertera pada Gambar 12 . 


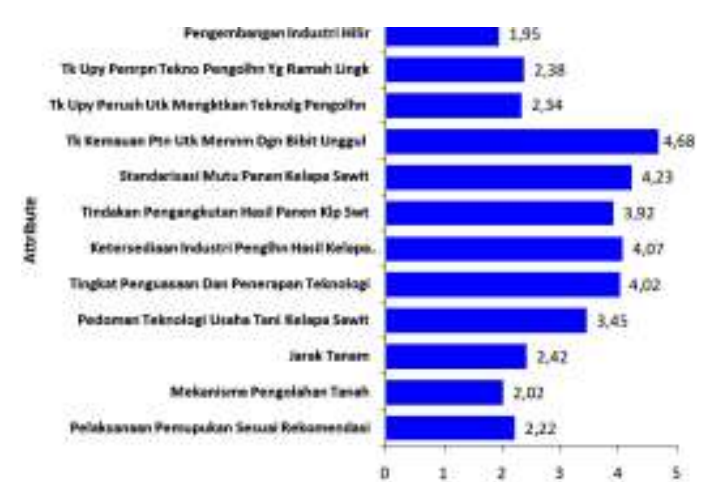

Gambar 12. Sensitivitas atribut dimensi teknologiinfrastruktur

Ketersediaan dan kemauan untuk mempergunakan bibit unggul adalah sangat penting, hal ini berhubungan langsung dengan potensi produksi per hektar yang akan dicapai oleh petani.Standarisasi mutu panen kelapa dan batas waktu pengiriman TBS ke pabrik haruslah diperhatikan agar kualitas TBSterjaga baik.

Disamping itu ketersediaan industri pengolahan hasil (pabrik) kelapa sawit yang mampu menerima TBS petani, adalah faktor yang sangat penting disampingtingkat penguasaan dan penerapan teknologi yang menunjang terhadap efisensi dan efektifitas usaha tani.

\section{Analisis Dimensi Hukum-Kelembagaan}

Berdasarkan hasil analisis ordinasi dimensi hukum-kelembagaan pada pengelolaan perkebunan kelapa sawit pola inti-plasma di PT. Bio Nusantara Teknologi kabupaten Bengkulu Tengahberada pada nilai 42,20 dengan status kurang berkelanjutan. Hal ini berarti bahwa pengelolaan pada aspek hukum-kelembagaan saat ini masih kurang dan memerlukan perhatian/perbaikan, seperti yang tertera pada Gambar 13.

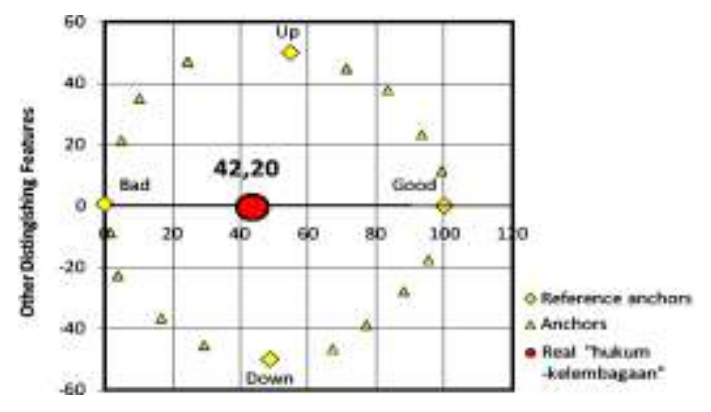

Gambar 13. Analisis keberlanjutan dimensi hukumkelembagaan
Dari hasil analisis leverage menunjukkan terdapat empat atribut utama yang paling sensitif pada dimensi hukum kelembagaan, yaitu: (1) keikutsertaan petani dalam kelompok tani, (2) keberadaan kelompok tani, (3) keberadaan lembaga keuangan mikro, dan (4) pemanfaatan skim pelayanan pembiayaan, seperti yang tertera pada Gambar 14.

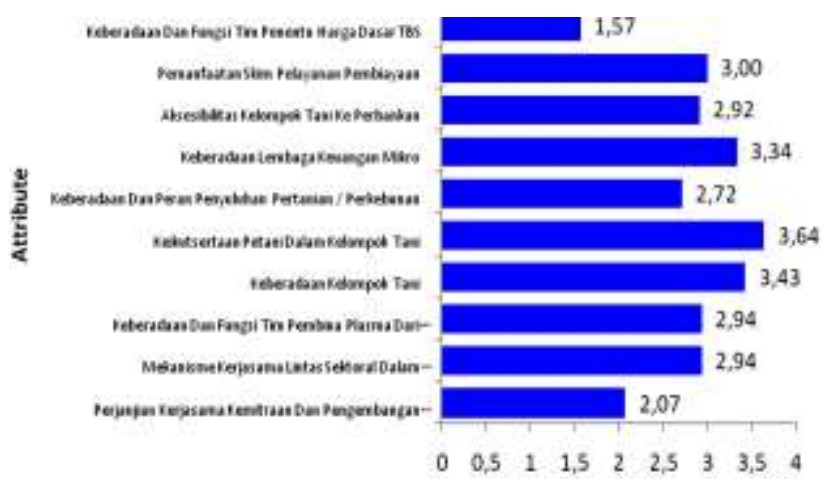

Gambar 14. Sensitivitas atribut dimensi hukum-

kelembagaan

Fungsikelembagaan kelompok tani adalah begitu dominan dan sangat penting, hal ini sesuai dengan syarat utama didalam kemitraan pola inti plasma yang mengharuskan para petani menjadi anggota kelompok tani, dan segala bentuk kesepakatan perjanjian antara perusahaan inti dengan para petani plasma melalui kelompok taninya. Disamping itu faktor keberadaan lembaga keuangan mikro serta pembiayaan skim pelayanan pembiayaan merupakan faktor yang paling sering dikeluhkan oleh petani plasma kebun kelapa sawit pada saat ini, jika dicermati lebih mendalam permasalahan utamanya adalah kurangnya bahkan belum adanya dukungan dalam permodalan usaha tani yang berkaitan dengan kelembagaan yang ada, sedangkan petani apabila secara mandiri mengusahakan permodalan terbentur pada sistem dan prosedur penyaluran permodalan/kredit yang rumit dan birokratis, dan cenderung tidak semua persyaratan dapat dipenuhi oleh petani.

\section{KESIMPULANDAN SARAN}

Status keberlanjutan pengelolaan perkebunan kelapa sawit pola inti-plasma PT. Bio Nusantara Teknologi Kabupaten Bengkulu Tengah yang 
berdasarkan atas lima dimensi, berada pada nilai indeks 53,18 dengan status Cukup Berkelanjutan. Dimensi Sosial-Budaya dengan indeks tertinggi 60,10 (Cukup Berkelanjutan), selanjutnya dimensi Ekonomi dengan indeks 58,41 (Cukup Berkelanjutan), dimensi Ekologi dengan indeks 56,01 (Cukup Berkelanjutan), dimensi Teknologi-Infrastruktur dengan indeks 49,17 (Kurang Berkelanjutan), dan dimensi Hukum-Kelembagaan dengan indeks terendah 42,19 (Kurang Berkelanjutan).

Atribut yang paling sensitif dan berpengaruh terhadap keberlanjutan pengelolaan perkebunan kelapa sawit pola inti-plasma PT. Bio Nusantara Teknologi Kabupaten Bengkulu Tengah, yaitu: (a) Ekologi: jumlah bulan kering, tingkat serangan hama dan penyakit, tindakan konservasi pada lahan miring, dan kelas kesesuaian lahan. (b) Ekonomi: tingkat pemberdayaan petani dan keuntungan usaha tani kelapa sawit. (c) Sosial-budaya: rata-rata umur petani dan rata-rata pendidikan formal petani. (d) Teknologi-infrastruktur: tingkat kemauan petani untuk menanam dengan bibit unggul dan standarisasi mutu panen kelapa sawit.(e) Hukum-kelembagaan: keikutsertaan petani dalam kelompok tani dan keberadaan kelompok tani.

Untuk meningkatkan keberlanjutan pengelolaan perkebunan kelapa sawit pola intiplasma di PT. Bio Nusantara Teknologi Kabupaten Bengkulu Tengah, dan di Provinsi Bengkulu pada umumnya, maka seluruh pemangku kebijakan perlu segera mengambil langkah-langkah perbaikan kebijakan yang tepat dengan memprioritaskan pada atribut yang paling sensitif pada dimensi yang kurang berkelanjutan pada penelitian ini, yaitu: Penggunaan Bibit Unggul Kelapa Sawit serta Pemberdayaan Kelembagaan Kelompok Tani.

\section{DAFTAR PUSTAKA}

Arifin. T. 2008. Akuntabilitas dan Keberlanjutan Pengelolaan Kawasan Terumbu Karang di Selat Lembeh, Kota Bitung. (Disertasi), Sekolah Pascasarjana Institut Pertanian Bogor. Bogor: 173 hal.
Charles AT. 2000. Sustainability Fishery System. Sain Mary's University Halifax, Nova Scotia, Canada. $370 \mathrm{p}$

Ditjenbun (Direktorat Jenderal Perkebunan) Kementerian Pertanian. 2015. Statistik Perkebunan Indonesia 2013 - 2015. Kelapa Sawit. 68 hal.

Fauzi, A. dan S. Anna.2005. Pemodelan Sumberdaya Perikanan dan Kelautan untuk Analisis Kebijakan. Gramedia Pustaka. Jakarta.

Kavanagh P. 2001.Rapid Appraisal of Fisheries (RAPFISH) Project. University of British Columbia, Fisheries Centre.

Ruslan, Sabiham, S., Sumardjo, dan Manuwoto, 2013.Evaluasi Keberlanjutan Pengelolaan Perkebunan Kelapa Sawit Pola Inti-Plasma Di PT. Perkebunan Nusantara VII Muara Enim, Sumatera Selatan. Jurnal Ekologia, Vol. 13 No.1, April 2013: 33-44

Pitcher, T.J. and Preikshot, D.B. 2001. Rapfish: A Rapid Appraisal Technique to Evaluate the Sustainability Status of Fisheries. Fisheries Research 49(3): 255-270.

Sabiham S. 2005. Manajemen sumberdaya lahan dalam usaha pertanian berkelanjutan .Makalah Seminar Nasional Himpunan Mahasiswa Ilmu Tanah "Save our Land for the Better Environment" Bogor.

Suwarno, J. 2011. Pengembangan Kebijakan pengelolaan berkelanjutan DAS Ciliwung Hulu, Kabupaten Bogor. (Disertasi).Program Studi Pengelolaan Sumberdaya Alam dan Lingkungan, SekolaPascasarjana, Institut Pertanian Bogor, Bogor. 